\title{
Does human influence on coastal grasslands habitats affect predation pressure on snakes?
}

\author{
Mauricio Beux dos Santos ${ }^{1,5}$, Mauro Cesar Lamim Martins de Oliveira ${ }^{2}$, Tatiane Penteado Gonçalves ${ }^{3}$, \\ Francis de Mattos Almeida ${ }^{3}$, Daniel Loebmann ${ }^{3}$ \& Alexandro Marques Tozetti ${ }^{4}$ \\ ${ }^{1}$ Programa de Pós-graduação em Biodiversidade Animal, \\ Centro de Ciências Naturais e Exatas, Universidade Federal de Santa Maria - UFSM, \\ Av. Roraima, s/n, Camobi, CEP 97105-000, Santa Maria, RS, Brasil \\ ${ }^{2}$ Laboratório de Ictiologia, Programa de Pós-graduação em Oceanografia Biológica, \\ Instituto de Oceanografia, Universidade Federal de Rio Grande-FURG, Campus Carreiros, CP 474, \\ CEP 96201-900, Rio Grande, RS, Brasil \\ ${ }^{3}$ Laboratório de Ecologia de Vertebrados Terrestres, Instituto de Ciências Biológicas, \\ Universidade Federal do Rio Grande - FURG, Av. Itália, Km 8, CEP 96201-900, Rio Grande, RS, Brasil \\ ${ }^{4}$ Universidade do Vale do Rio dos Sinos - UNISINOS, Av. Unisinos, 950, \\ CEP 93022-000, São Leopoldo, RS, Brasil \\ ${ }^{5}$ Corresponding author: Mauricio Beuxdos Santos, e-mail: mbeuxs@yahoo.com.br
}

SANTOS, M.B., OLIVEIRA, M.C.L.M., GONÇALVES, T.P., ALMEIDA, F.M., LOEBMANN, D. \& TOZETTI, A.M. Does human influence on coastal grasslands habitats affect predation pressure on snakes? Biota Neotrop. 13(1): http://www.biotaneotropica.org.br/v13n1/en/abstract?short-communication+bn01913012013

\begin{abstract}
The loss and modification of habitats by humans have been considered key factors in the decline of diversity of species worldwide. However, the real effect caused by these disturbances on the biota is still poorly understood. The assessment of the changes in the network of interspecific interactions, such as predation rates on the native fauna, can be an important tool to diagnose the functionality of disturbed ecosystems. In this study we evaluate the predation rate on snakes in coastal grasslands in South America under human influence. Predation rate of artificial snakes, unlike that obtained in other studies, was lower in human-altered areas than preserved ones. Our findings may be due to a reduction in the abundance and/or richness of species of native predators in more disturbed areas.
\end{abstract}

Keywords: reptiles, coastal dunes, human impact, predation, Brazil.

SANTOS, M.B., OLIVEIRA, M.C.L.M., GONÇALVES, T.P., ALMEIDA, F.M., LOEBMANN, D. \& TOZETTI, A.M. A influência humana afeta a pressão de predação em serpentes em ambientes de campos costeiros? Biota Neotrop. 13(1): http://www.biotaneotropica.org.br/v13n1/pt/abstract?short-communication+bn01913012013

Resumo: A perda e modificação de habitats por seres humanos têm sido consideradas fatores chave no declínio da diversidade de espécies em todo o mundo. No entanto, o efeito real causado por estes distúrbios sobre a biota ainda é pouco compreendido. A avaliação das mudanças na rede de interações interespecíficas, como as taxas de predação sobre a fauna nativa, pode ser uma importante ferramenta para diagnosticar a funcionalidade dos ecossistemas perturbados. Neste estudo foi avaliada a taxa de predação de serpentes em campos costeiros na América do Sul sob a influência humana. A taxa de predação de serpentes artificiais, ao contrário do que foi observado em outros estudos, foi menor em áreas antropizadas do que em áreas preservadas. Esse resultado pode ser devido a uma redução na abundância e/ou riqueza de espécies de predadores nativos nas áreas perturbadas. Palavras-chave: répteis, dunas costeiras, impacto humano, predação, Brasil. 


\section{Introduction}

The loss of natural habitats is considered the main factor for the decline of populations and local extinction of species (Wilcove et al. 1998, Vié et al. 2009). Habitat loss is not limited to destruction or substitution, but also changes in basic characteristics (i.e. soil proprieties, sunlight, humidity, and vegetation cover), sometimes making them unsuitable for native species (Hobbs 1987, Campos et al. 2006).

In addition, habitat changes can isolate populations, modify migration, genetic flow patterns, and interspecific interactions (Lillywhite \& Henderson 1993, Shine \& Fitzgerald 1996, Újvári et al. 2002). Changes in the patterns of interactions may be a consequence of disturbances on habitat (Polis 1981, Ricklefs 2003, May et al. 2007). An example is the increase in predator population (Robinson \& Wilcove 1994, Oehler \& Litvaitis 1996) in altered areas, resulting in a negative impact on local communities (Connell 1975, Jaksić et al. 1982). The action of predators can drastically reduce prey populations, especially when they are confined in small fragments of habitat, and even result in local extinctions (Andren \& Angelstam 1988, Oehler \& Litvaitis 1996). By this way, the study of the networks of interactions among species has become an important tool to diagnose the functionality of ecosystems after human disturbances in their habitat.

However, unlike with birds and mammals, little is known on the general effects of habitat changes on reptile assemblages (Gibbons et al. 2000, Kjoss \& Litvaitis 2001). This is even more concerning since reptiles are especially vulnerable to changes in their habitat, due to their limited ability of dispersion and low fecundity (Congdon et al. 1993).

The Neotropical region harbors a large variety of reptile species and habitats, many under human pressure (Seeliger 2003). In Brazil most studies on the interface conservation/habitat/fauna has been conducted in forests, while grasslands are poorly known (Brasil 2004). For coastal grasslands in the southernmost Brazil, the lack of information is a reality and this area is considered a high priority study area (see Brasil 2004). Coastal grasslands in southernmost Brazil have been gradually cleared for the expansion of urban areas, agriculture, and cattle ranching (Seeliger et al. 2000, Seeliger 2003, Rio Grande do Sul 2007). Thus, these habitats are laboratories for studies on human impact on the native fauna (Tozetti et al. 2010).

In the last decades, predator-prey interactions have been examined using assays with plasticine replicas for several animal groups, such as salamanders (Kuchta 2005), birds (Keyser et al. 1998, Roos 2002), lizards (Castilla \& Labra 1998, Shepard 2007) and snakes (e.g. Madsen 1987, Buasso et al. 2006, Mitrovich \& Cotroneo 2006, Sherbrooke \& Westphal 2006, Pfennig et al. 2007, Harper Junior \& Pfennig 2008). Because they are an efficient alternative to direct observation of predation, this method is a tool for studies on interactions or evolutionary processes (Pfennig et al. 2001). Therefore, the present study aimed at assessing the predation rate on artificial snakes in coastal grasslands with different levels of human influence in a southernmost area of Brazil.

\section{Materials and Methods}

\section{Study area}

The study was conducted in coastal grasslands associated with sand dunes in a southernmost region of Brazil, municipality of Rio Grande, Rio Grande do Sul. The vegetation cover is sparse with predominance of grasses and short herbs associated with seasonal water bodies (Cordazzo \& Seeliger 1987, Calliari \& Klein 1993). The daily temperature varies widely, and can range between $0{ }^{\circ} \mathrm{C}$ and
$40{ }^{\circ} \mathrm{C}$ in the same day, due to the low density of the vegetation and the sandy soil (Calliari \& Klein 1993). The climate of the region is classified as superhumid mesothermal, with average annual maximum temperature of $23.3^{\circ} \mathrm{C}$ and minimum of $12.7^{\circ} \mathrm{C}$. The seasons are well defined, rainfall is homogeneously distributed throughout the year and the average total annual precipitation is $1.252 \mathrm{~mm}$ (Maluf 2000). The region encompasses one of the last remnants of relatively well-preserved coastal grasslands in Brazil. However, this area has been gradually cleared for the expansion of urban and agricultural areas or transformed in pastures for cattle ranching (Seeliger et al. 2000). Experiments were conducted inside an area of approximately 3000 ha of extension of continuous native coastal grassland located between the pairs of coordinates $32^{\circ} 07^{\prime} 54.65^{\prime \prime} \mathrm{S} ; 52^{\circ} 06^{\prime} 38.80^{\prime \prime} \mathrm{O}$ and $32^{\circ} 17^{\prime} 35.07^{\prime \prime} \mathrm{S} ; 52^{\circ} 20^{\prime} 53.36^{\prime \prime} \mathrm{O}$, approximately at sea level (Figure 1). The area exhibits dispersed human settlements consisted of small groups of families of farmers, cattle ranchers or fishers at the subsistence level. The spatial distribution of the settlements is disorganized and dispersed with extensive uninhabited areas and relatively well-preserved vegetal cover.

\section{Sampling design}

To examine the relationship between aspects of habitat changes and predation pressure on snakes, two sampling subareas were compared. One of them was a predominantly man-altered habitat and the other, predominantly preserved habitats. The classification of the human interference in these two subareas was defined based on a pilot study. In this stage, 12 transect of $800 \mathrm{~m}$ in length and at least $2 \mathrm{~km}$ apart were set out. The transects were run during five days each month between 08:00 and 5:00 PM between April 2009 and March 2010.

Areas with preserved habitats were defined as those at least 10 $\mathrm{km}$ away from any settlement and that during pilot monitoring of transects exhibited the following characteristics: (a) absence of signs of cattle activity as tracks or scats, (b) domestic animals (dogs and cats) rarely observed (less than one record per month), (c) low traffic in the nearest road (less than one record every five hours), (d) low traffic of people (less than one per month). Human-altered habitats were defined as those less than $10 \mathrm{~km}$ from human settlements where: (a) cattle were frequently observed (more than five observations per month), (c) other domestic animals commonly observed (more than one record per month), (d) moderate to high traffic of vehicles and people (at least ten records per month).

\section{Assessment of Snake Predation}

After the pilot study, two sampling subareas of approximately 10 ha were established. One was classified as "human-altered habitat" and the other as "preserved habitat". The assessment of predation consisted of examining imprints of predation attempts on plasticine replicas of snakes distributed in the two habitats. Each model was approximately $20 \mathrm{~cm}$ long and $20 \mathrm{~g}$. The coloration was olive green, similar to the color pattern of species commonly found in the region (e.g. Liophis jaegeri (Güther 1858), L. poecilogyrus (Wied 1953); Quintela et al. 2006, 2011).

In each area (preserved and human-altered), 60 artificial snakes were arranged in three groups of 20 snakes each, separated by a distance of at least $200 \mathrm{~m}$. In each group, snakes were placed on the substrate $10 \mathrm{~m}$ apart from each other and their location was recorded with GPS. Artificial snakes were placed in portions of the substrate with low density of vegetation, minimizing variations in vegetal cover between areas. The replicas remained in the habitats for three consecutive days. At the end of this period, artificial snakes were located and examined for imprints of predators. "Predated" models were defined as those removed or with marks of beaks, scratches or lacerations. Marks by insects, such as beetles or ants, were not accounted in the analysis. 


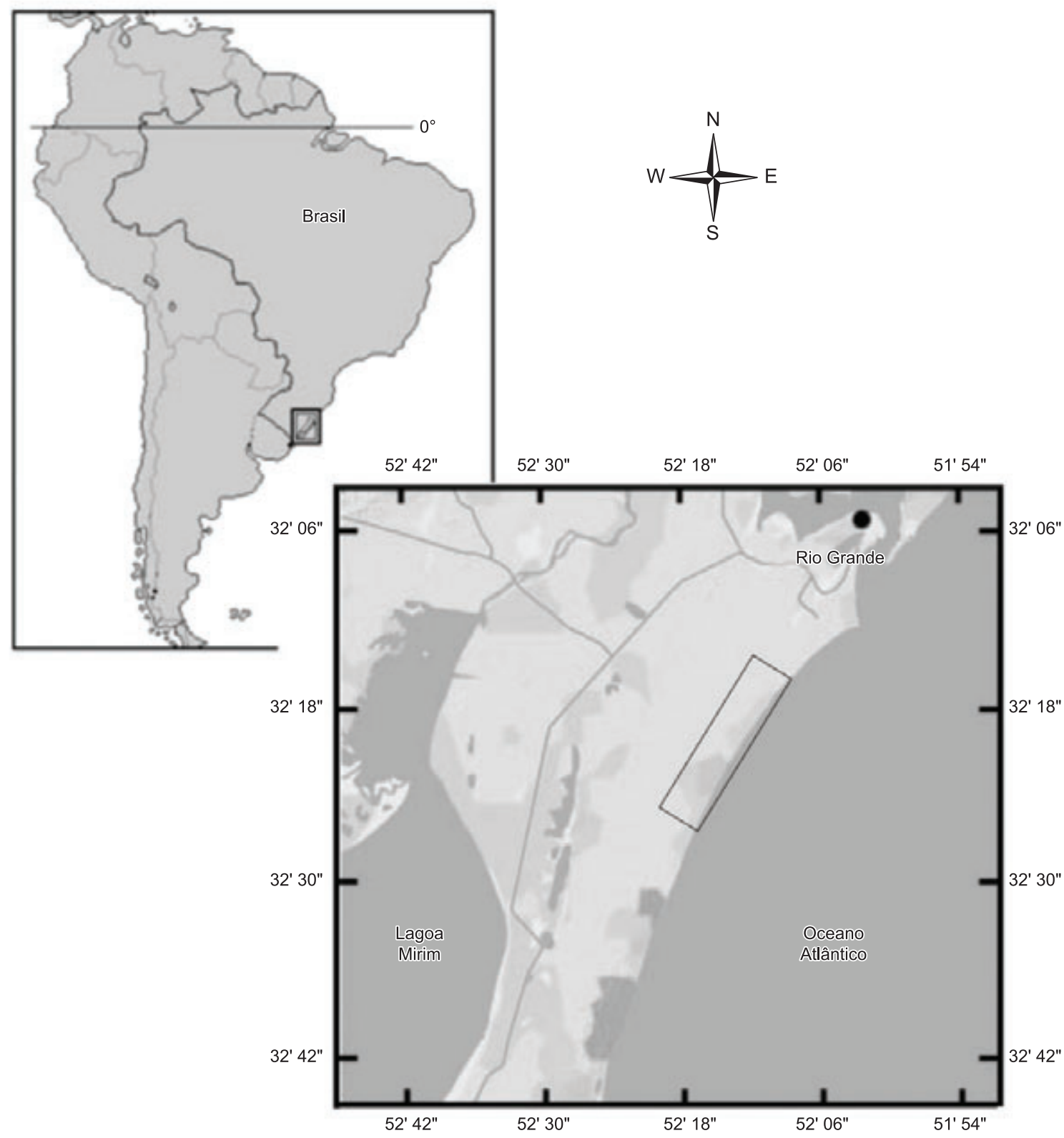

Figure 1. Study area and sampling design.

\section{Data analysis}

Predation was evaluated by calculating the predation rate, defined as the number of predation events divided by the number of artificial snakes (number of events/total number of snakes). Predation rates for artificial snakes attacked in the two habitats were compared with the Mann-Withney test. Differences between the number of attacks to artificial snakes among repetitions in each habitat were verified with the Kruskal Wallis test. All differences were considered significant when $\mathrm{p} \leq 0.05$ (Zar 1999).

\section{Results}

Of the 120 artificial snakes, 69 (57\%) exhibited marks of attempted predation. Fewer predation events were observed in the human-altered habitat ( 25 events or $36.2 \%$ of the snakes) than in the preserved habitat (44 events or $63.8 \%$ of the attacked snakes; Table 1). The predation rate in the preserved area was 1.76 times higher than that in the human altered habitat.

The predation rate was significantly higher in the preserved area (mean $=0.30$; variation $=0.09-0.50)$ than in the human-altered area $($ mean $=0.15$; variation $=0.03-0.2 ; \mathrm{U}=4122.5 ; \mathrm{P}=0.004$; $\mathrm{n}=60)$. The predation rate varied significantly among the patches of the natural area $\left(\mathrm{H}_{[2 ; 60]}=9.01 ; \mathrm{p}=0.0110\right)$. However, this variation was not significant among the patches of the human-altered area $\left(\mathrm{H}_{[2 ; 60]}=0,11 ; \mathrm{p}=0,9463\right)$.

In both areas, the most common event was the removal of snakes, totaling 28 records in the preserved grassland and 13 in the humanaltered area (Table 1). We observed three lacerations in the artificial snakes, all in the human-altered habitat, and a total of 23 marks of beaks, of which 15 were in the preserved habitat and eight in the 

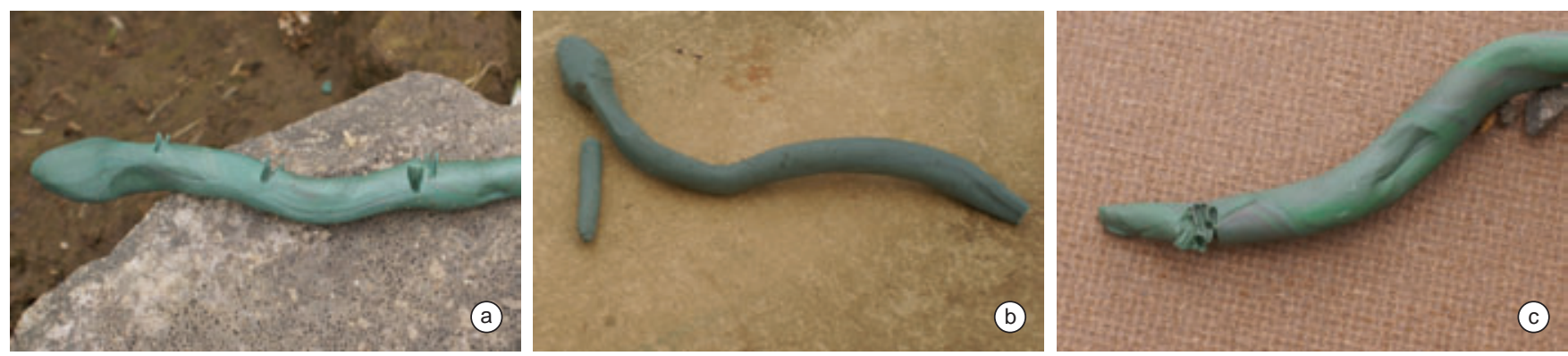

Figure 2. General aspect of imprints of predatory attacks to artificial snakes. a) beak imprint; b) laceration; c) scratch.

Table 1. Absolute number of predatory attacks on artificial snakes in coastal grasslands with different levels of human disturbance in southernmost Brazil.

\begin{tabular}{lccccc}
\hline \multirow{2}{*}{ Habitat } & \multicolumn{5}{c}{ Type of attack } \\
\cline { 2 - 6 } & Laceration & Beak & Removal & Scratch & Total \\
\hline Preserved & 0 & 15 & 28 & 1 & 44 \\
Human-altered & 3 & 8 & 13 & 1 & 25 \\
Total & 3 & 23 & 41 & 2 & 69 \\
\hline
\end{tabular}

human-altered habitat. Claw marks, although relatively rare (one record for each habitat) were probably made by small mammals (Figure 2).

\section{Discussion}

Reptiles, especially snakes, represent an important food source for a large number of vertebrates, especially birds and mammals (Greene 1997, Hinman et al. 1997, Buasso et al. 2006, Tozetti et al. 2009). However, little is known on how the habitat interferes in predation rates or whether habitat changes can maximize the action of a given type of predator. Our findings allow generalizations on human influence on predation pressure on snakes.

Usually, the difference in the predation rate might be associated to a higher density and/or richness of predator species in the preserved area (see McKinney 2002). However, a large number of studies have reported higher predation rates of the native fauna in human-altered areas due to the introduction of exotic species of predators, such as mammals (Mackin-Rogalska et al. 1988) and birds (Marzluff 2001, Ruxton et al. 2002).

However our data suggests a lower predation rate of snakes in altered area, probably due to the reduction in the number of native predators. We believe that birds exercises the more intense predation pressure on snakes as showed in other studies (e.g. Brodie 1993, Hinman et al. 1997, Pfennig et al. 2001). In fact, despite the intense search and low density of vegetal cover, the removed models were not found, possibly removed by birds of prey (Wilgers \& Horne 2007). The human disturbance in study site may be a factor which contributes for decreasing of the birds' density, a important predators of snakes (Marzluff 2001).

Our results suggest a change in the network of ecological interaction in the studied area. This is a concerning situation, given the threat and intensity with which coastal areas have been modified throughout Brazil.

\section{References}

ANDREN, H. \& ANGELSTAM, P. 1988. Elevated predation rates as an edge effect in habitat islands: experimental evidence. Ecology 69(2):544-547. http://dx.doi.org/10.2307/1940455

BRASIL. Ministério do Meio Ambiente - MMA. 2004. Segundo Relatório Nacional para a Convenção sobre Diversidade Biológica. Diretoria do Programa Nacional de Conservação da Biodiversidade. Distrito Federal, Brasília.

BRODIE, E.D. 1993. Differential Avoidance of Coral Snake Banded Patterns by Free-Ranging Avian Predators in Costa Rica. Evolution 47(1):227-235. http://dx.doi.org/10.2307/2410131

BUASSO, C.M., LEYNAUD, G.C. \& CRUZ, F.B. 2006. Predation on snakes of Argentina: Effects of coloration and ring pattern on coral and false coral snakes. Stud. Neotrop. Fauna. E. 41(3):183-188. http://dx.doi. org/10.1080/01650520600630725

CALLIARI, L.J. \& KLEIN, A.H.F. 1993. Características morfodinâmicas e sedimentológicas das praias oceânicas entre Rio Grande e Chuí, RS. Pesquisas. 20(1):48-56.

CAMPOS, J.B., TOSSUlinO, M.G.P. \& MÜLLER, C.R. 2006. Unidades de conservação, ações para valorização da biodiversidade. Instituto ambiental do Paraná, Curitiba.

CASTILLA, A.M. \& LABRA, A. 1998. Predation and spatial distribution of the lizard Podarcis hispanica atrata: an experimental approach. Acta. Oecol. 19(2):107-114. http://dx.doi.org/10.1016/S1146-609X(98)80014-3

CONGDON, J.D., DUNHAM, A.E. \& VAN LOBEN SELS, R.C. 1993. Delayed Sexual Maturity and Demographics of Blanding's Turtles (Emydoidea blandingii): Implications for Conservation and Management of Long-Lived Organisms. Conserv. Biol. 7(4):826-833. http://dx.doi. org/10.1046/j.1523-1739.1993.740826.x

CONNELL, J.H. 1975. Some mechanisms producing structure in natural communities: a model and evidence from field experiments. In Ecology and evolution of communities (M.L. Cody \& J.M. Diamond, eds). Balknap press, Cambridge, Massachusetts, p.460-490.

CORDAZZO, C.V. \& SEELIGER, U. 1987. Composição e distribuição da vegetação nas dunas costeiras ao sul do Rio Grande (RS). Cienc. Cult. 39(3):321-324.

GIBBONS, J.W., SCOTT, D.E., RYAN, T.J., BUHLMANN, K.A., TUBERVILLE, T.D., METTS, B.S., GREENE, J.L., MILLS, T., LEIDEN, Y., POPPY, S. \& WINNE, C.T. 2000. The global decline of reptiles, déjà vu amphibians. Bioscience. 50(8):653-666. http://dx.doi. org/10.1641/0006-3568(2000)050[0653:TGDORD]2.0.CO;2

GREENE, H.W. 1997. Snakes: the evolution of mystery in nature. University of California Press, California.

HARPER JUNIOR, G.R. \& PFENNIG, D.W. 2008. Mimicry on the edge: why do mimics vary in resemblance to their model in different parts of their geographical range? Proc. Biol . Sci. 274:1955-1961. PMid:17567563 PMCid:2275182. http://dx.doi.org/10.1098/rspb.2007.0558 
HINMAN, K.E., THROOP, H.L., ADAMS, K.L., DAKE, A.J., McLAUCHLAN, K.K. \& McKONE, M.J. 1997. Predation by freeranging birds on partial coral snake mimics: the importance of ring width and color. Evolution. 51(3):1011-1014. http://dx.doi.org/10.2307/2411177

HOBBS, R.J. 1987. Disturbance regimes in remnants of natural vegetation. In Nature Conservation: The Role of Remnants of Native Vegetation (D.A. Saunders, G.W. Arnold, A.A. Burbidge \& A.J.M. Hopkins, eds). Surrey Beatty and Sons, Chipping Norton, p.151-162.

JAKSIĆ, F.M., GREENE, H.W., SCHWENK, K. \& SEIB, R.L. 1982. Predation upon Reptiles in Mediterranean Habitats of Chile, Spain and California: A Comparative Analysis. Oecologia 53(2):152-159. http:// dx.doi.org/10.1007/BF00545658

KEYSER, A.J., HILL, G.E. \& SOEHREN, E.C. 1998. Effects of Forest Fragment Size, Nest Density, and Proximity to Edge on the Risk of Predation to Ground-Nesting Passerine Birds. Conserv. Biol. 12(5):986-994. http://dx.doi.org/10.1046/j.1523-1739.1998.97177.x

KJOSS, V.A. \& LITVAITIS, J.A. 2001. Community structure of snakes in a human-dominated landscape. Biol. Conserv. 98(3):285-292. http://dx.doi. org/10.1016/S0006-3207(00)00167-1

KUCHTA, S.R. 2005. Experimental Support for Aposematic Coloration in the Salamander Ensatina eschscholtzii xanthoptica: Implications for Mimicry of Pacific Newts. Copeia 2:265-271. http://dx.doi.org/10.1643/ CH-04-173R

LILLYWHITE, H.B. \& HENDERSON, R.W. 1993. Behavioral and functional ecology of arboreal snakes. In Snakes, ecology and behavior (R.A. Seigel \& J.T. Collins, eds.). McGraw-Hill Companies, New York, p.1-48.

MACKIN-ROGALSKA, R., PINOWSKI, J., SOLON, J. \& WOJCIK, Z. 1988. Changes in vegetation, avifauna, and small mammals in a suburban habitat. Pol. Ecol. Stud. 14:293-330.

MADSEN, T. 1987. Are juvenile grass snakes, Natrix natrix, aposematically coloured? Oikos. 48(3):265-267. http://dx.doi.org/10.2307/3565512

MALUF, J.R.T. 2000. Nova classificação climática do Estado do Rio Grande do Sul. Rev. Bras. Agromet. 8(1):141-150.

MARZLUFF, J.M. 2001. Worldwide urbanization and its effects on birds. In Avian Ecology in an Urbanizing ( J.M. Marzluff, R. Bowman \& R. Donnelly, eds.). Kluwer, World Norwell, p.19-47.

MAY, R.M., CRAWLEY, M.J. \& SUGIHARA, G. 2007. Communities: patterns. In Theoretical Ecology Principles and Applications (R.A.M. May \& A.R. McLean, eds.). Oxford University Press Inc., New York, p.7-16. PMid:17997635.

McKINNEY, M.L. 2002. Urbanization, Biodiversity, and Conservation. Bioscience 52(10):883-890. http://dx.doi.org/10.1641/00063568(2002)052[0883:UBAC]2.0.CO;2

MITROVICH, M.J. \& COTRONEO, R.A. 2006. Use of plasticine replica snakes to elicit antipredator behaviour in the California ground squirrel (Spermophilus beecheyi). Southwest. Nat. 51(2):263-267. http://dx.doi. org/10.1894/0038-4909(2006)51[263:UOPRST]2.0.CO;2

OEHLER J.D. \&, LITVAITIS, J.A. 1996. The role of spatial scale in $\sim$ tnderstanding responses of medium-sized carnivores to forest fragmentation. Can. J. Zoolog. 74:2070-2079. http://dx.doi.org/10.1139/ z96-235

PFENNIG, D.W., HARCOMBE, W.R. \&, PFENNIG, K.S. 2001. Frequencydependent Batesian mimicry. Nature. 410(6826):323. PMid:11268195. http://dx.doi.org/10.1038/35066628

PFENNIG, D.W., HARPER, G.R., BRUMO, A.F., HARCOMBE, W.R. \& PFENNIG, K.S. 2007. Population differences in predation on Batesian mimics in allopatry with their model: selection against mimics is strongest when they are common. Behav. Ecol. Sociobiol. 61:505-511. http://dx.doi. org/10.1007/s00265-006-0278-x

POLIS, G.A. 1981. The evolution and dynamics of intraspecifi c predation. Annu. Rev. Ecol. Syst. 12:225-251. http://dx.doi.org/10.1146/annurev. es.12.110181.001301
QUiNTElA, F.M., LOEBMANN, D. \& GIANUCA, N.M. 2006. Répteis continentais do município de Rio Grande do Sul, Brasil. Biosciências. 14(2):180-188.

QUINTELA, F.M., PINHEIRO, R.M. \& LOEBMANN, D. 2011. Composição e uso do habitat pela herpetofauna em uma área de mata paludosa da Planície Costeira do Rio Grande do Sul, extremo sul do Brasil. R. Bras. Bioci. 9(1):6-11

RICKLEFS, R.E. 2003. Economia da Natureza. Guanabara Koogan, Rio de Janeiro.

RIO GRANDE DO SUL. Secretaria do Planejamento e Gestão - SPG. 2007. Projeto Conservação da Biodiversidade como Fator de Contribuição ao Desenvolvimento do Estado do Rio Grande do Sul. http://www.seplag. rs.gov.br/index.asp (último acesso em 03/04/2011).

ROBINSON, S.K. \& WILCOVE, D.S. 1994. Forest fragmentation in the temperate zone and its effects on migratory songbirds. Bird. Conserv. Int. 4:233-249. http://dx.doi.org/10.1017/S0959270900002793

ROOS, S. 2002. Functional response, seasonal decline and landscape differences in nest predation risk. Oecologia 133(4):608-615. http:// dx.doi.org/10.1007/s00442-002-1056-8

RUXTON, G.D., THOMAS, S. \& WRIGHT, J.W. 2002. Bells reduce predation of wildlife by domestic cats (Felis catus). J. Zool. 256(1):81-83. http:// dx.doi.org/10.1017/S0952836902000109

SEELIGER, U. 2003. Response of southern brazilian coastal foredunes to natural and human-induced disturbance. J. Coastal. Res. 35:51-55.

SEELIGER, U., CORDAZZO, C.V. \& OLIVEIRA, C.P.L. 2000. Longterm changes of coastal foredunes in the Southern Atlantic. J. Coastal. Res. 16(4):1068-1072.

SHEPARD, D.B. 2007. Habitat but not body shape affect predator attack frequency on lizard models in the brazilian cerrado. Herpetologica 63(2):193-202. http://dx.doi.org/10.1655/00180831(2007)63[193:HBNBSA]2.0.CO;2

SHERBROOKE, W.C. \& WESTPHAL, M.F. 2006. Responses of greater roadrunners during attacks on sympatric venomous and nonvenomous snakes. Southwest. Nat. 51(1):41-47. http://dx.doi.org/10.1894/00384909(2006)51[41:ROGRDA]2.0.CO;2

SHINE, R. \& FITZGERALD, M. 1996. Large snakes in a mosaic rural landscape: the ecology of carpet pythons Morelia spilota (Serpentes: Pythonidae) in coastal eastern Australia. Biol. Conserv. 76:113-122. http://dx.doi.org/10.1016/0006-3207(95)00108-5

TOZETTI, A.M., OLIVEIRA, R.B. \& PONTES, G.M.F. 2009. Defensive repertoire of Xenodon dorbignyi (Serpentes, Dipsadidae). Biota Neotrop. 9:1-7. http://dx.doi.org/10.1590/S1676-06032009000300016

TOZETTI, A.M., PONTES, G.M.F., MARTINS, M.B. \& OLIVEIRA, R.B. 2010. Temperature preferences of Xenodon dorbignyi: field and experimental observations. Herpetol. J. 20:277-280.

ÚJVÁRI, B., MADSEN, T., KOTENKO, T., OLSSON, M., SHINE, R. \& WITTZELL, H. 2002. Low genetic diversity threatens imminent extinction for the Hungarian meadow viper (Vipera ursinii rakosiensis). Biol. Conserv. 105:127-130. http://dx.doi.org/10.1016/S00063207(01)00176-8

VIÉ, J.C., HILTON-TAYLOR, C. \& STUART, S.N. (EDS.) 2009. Wildlife in a Changing World-An Analysis of the 2008 IUCN Red List of Threatened Species. IUCN, Gland, Switzerland, 180p.

WILCOVE, D.S., ROTHSTEIN, D., DUBOW, J., PHILLIPS, A. \& LOSOS, E. 1998. Quantifying threats to imperiled species in the United States. Bioscience. 48(8): 607-615. http://dx.doi.org/10.2307/1313420

WILGERS, D.J. \& HORNE, E.A. 2007. Spatial variation in predation attemps on artificial snakes in a fire-disturbed tallgrass prairiethe. Southwest. Nat. 52(2):263-270. http://dx.doi.org/10.1894/00384909(2007)52[263:SVIPAO]2.0.CO;2

ZAR, J.H. 1999. Biostatistical Analysis. Prentice-Hall, New Jersey. 